to be non-linear; terms in YEAR squared $(p<0.0001)$ and YEAR cubed $(p=0.04)$ significantly improved the fit of the model. The final model fitted well: residuals were appropriately distributed, no additional regression terms were needed, and a leverage analysis indicated that the results had not been distorted by unrepresentative data points.

In both sexes the fitted suicide rate for 1975 increased consistently with increasing age. Males exhibited a significantly higher rate of suicide than females within all age strata. In males the fitted rate ranged from 61.9 deaths per million per annum $(95 \%$ confidence interval 55.3 to $69 \cdot 3$ ) in the youngest age group to $189 \cdot 2$ ( 163.0 to $219 \cdot 5)$ deaths per million per annum in the oldest. In females the equivalent range was from $28 \cdot 4(23.9$ to $33 \cdot 7)$ to $107 \cdot 2(93 \cdot 1$ to $123 \cdot 4)$ deaths per million per annum.

Among males in each of the age groups 15-24, 25-34, and 35-44 the suicide rate increased significantly $(p<0.0001)$ between 1975 and 1987 (figure). No significant changes were observed in the older age groups. In sharp contrast, all females in all age groups showed a decline in suicide rate, ranging from a $33 \%$ fall $(p=0.002)$ in the age group $35-44$ to a $17 \%$ fall $(\mathrm{p}=0.055)$ in the group 25-34.

\section{Comment}

This analysis reinforces the findings of our local study and extends the scope of reports of the Office of Population Censuses and Surveys ${ }^{5}$; it suggests that important changes have occurred in the pattern of suicide among young men throughout England and Wales. Among men aged 15-24, in whom the rate of suicide had been fairly stable up to $1982,{ }^{5}$ the rate increased dramatically $(40 \%, 95 \%$ confidence interval $25 \%$ to $56 \%$ ) during $1982-7$. In contrast, the rate among men aged 25-34 and 35-44, which increased steeply during the late 1970 s and early 'eighties, ${ }^{5}$ seems to have stabilised and may even have started to fall. The suicide rate among women seems to have been falling throughout the period of the study, a finding that represents a continuation of earlier trends. ${ }^{5}$

As in our previous study ${ }^{4}$ our analysis permits no inference about the causes of changing suicide rates among young men. Changing patterns of drug and alcohol use, psychiatric ill health, and a vast array of possible social factors may all play an important part. It seems improbable that coroners throughout England and Wales have become more likely to return a verdict of suicide specifically in young men without any similar changes in relation to other age and sex groups; it therefore seems unlikely that our results are a consequence of recording artefact. The changes we have shown appear to be real, their magnitude is of considerable concern, and further study of the aetiology of these suicides is clearly needed.

ADDENDUM - The trend in suicides has since been emphasised by the mortality statistics for 1988, which show a further $18 \%$ increase (to 110.0 deaths per million per annum) in the suicide rate among men aged 15-24.

1 Lowy A, Burton P, Briggs A. Increasing suicide rates in young adults. Br Med $\mathcal{F}$

1990;300:643.
Mihill C. Suicides up in young men. Guardian 1990 March 9:3 ( $\mathrm{col} 2$ ).

2 Mihill C. Suicides up in young men. Guardian 1990 March 9:3 (col 2).
3 Office of Population Censuses and Surveys. Mortality statistics: cause. Office of Population Censuses and Surveys. Morta Series DH2. London: HMSO, 1977-89. (Nos 2-14.)

4 Aitkin M, Anderson D, Francis B, Hinde J. Statistical modelling in GLIM. Óxford: Clarendon Press, 1989.

Office of Population Censuses and Surveys. Suicides 1950-82. London: HMSO, 1984. (Population trends 35.)

(Accepted 21 May 1990)

\title{
Raised concentrations of antibodies to cardiolipin in patients receiving dialysis
}

\section{Carola Grönhagen-Riska, Anna-Maija Teppo, Antero Helanterä, Eero Honkanen, Heikki Julkunen}

Fourth Department of Medicine, Helsinki University Central Hospital, SF-00170 Helsinki, Finland Carola Grönhagen-Riska, $\mathrm{MD}$, head of nephrology unit Anna-Maija Teppo, MSC, head chemist, immunology laboratory

Antero Helanterä, BM, resident in nephrology Eero Honkanen, MD, specialist, nephrology unit Heikki Julkunen, BM, specialist, rheumatology unit

Correspondence to: Dr Grönhagen-Riska.

BrMed f 1990;300:1696-7
Clinical events such as recurrent arterial or venous thrombosis, spontaneous abortions, and thrombocytopenia have been associated with antibodies to cardiolipin. Many patients have simultaneously been positive for lupus anticoagulant and had clinically verified lupus erythematosus, but symptoms have also developed in patients without this underlying disease. Antibodies to cardiolipin may also be detected after bacterial or viral infections. ${ }^{1}$ Patients with uraemia have a high incidence of cardiovascular and thrombotic events. Infections form the second largest group of complications in these patients. ${ }^{2}$ Against this background we analysed the prevalence of raised concentrations of antibody to cardiolipin in a cross sectional study of patients receiving dialysis.

\section{Subjects, methods, and results}

We studied 146 patients receiving dialysis (34 receiving continuous ambulatory peritoneal dialysis and 112 receiving haemodialysis). Their mean age was 48 (range 13-76), and they had been receiving dialysis for a mean of 37 (0-252) months. Forty three patients had chronic glomerulonephritis (verified by biopsy), of whom six had systemic lupus erythematosus. Twenty seven had diabetic nephropathy, and 16 had amyloid- osis secondary to rheumatoid arthritis. Other diseases were polycystic kidney disease, chronic pyelonephritis, and interstitial nephritis. Fifty three healthy subjects and 32 consecutive patients with systemic lupus erythematosus served as controls.

IgG antibodies to cardiolipin in serum were analysed with a quantitative enzyme linked immunosorbent assay (ELISA) (Cheshire Diagnostics, Chester, England); international standards were used. In the 53 normal subjects the mean (SD) concentration of antibody was 3(3) $U / 1$ and $95 \%$ of the values were below $10 \mathrm{U} / 1$. Thus we regarded only values above $10 \mathrm{U} / 1$ as being positive and recorded only these numerically. Student's $t$ test for unpaired values and the $\chi^{2}$ test were used for statistical calculations.

The proportion of patients with a positive concentration of antibodies to cardiolipin among the patients receiving dialysis was significantly higher than that among the normal controls but about the same as that among the patients with systemic lupus erythematosus (table). Positive concentrations were, however, generally lower in the patients receiving dialysis than in those with systemic lupus erythematosus (mean $20 \mathrm{U} / 1$ ( $95 \%$ confidence interval 16 to $24 \mathrm{U} / \mathrm{l}$ ) $v 97$ (34 to 160 ) $\mathrm{U} / \mathrm{l} ; \mathrm{p}=0.001)$; the highest concentration in a patient receiving dialysis was $57 \mathrm{U} / \mathrm{l}$ compared with $200 \mathrm{U} / \mathrm{l}$ in a patient with systemic lupus erythematosus.

Among the patients receiving dialysis, having a positive antibody concentration was not associated with age or having received a transplant but was more common among the patients with chronic glomerulonephritis than among those with other diagnoses (table). Three of six patients with lupus nephritis had positive antibody concentrations. A higher proportion of patients with chronic glomerulonephritis than with other renal disease had received a transplant, and they had also been receiving dialysis for longer. Neither 


\begin{tabular}{|c|c|c|c|c|c|c|}
\hline & \multicolumn{2}{|c|}{ Antibody to cardiolipin } & \multirow[b]{2}{*}{$\begin{array}{c}\text { Mean age } \\
\text { (years) }\end{array}$} & \multirow{2}{*}{$\begin{array}{c}\text { Duration of dialysis } \\
\text { (95\% confidence } \\
\text { interval) (months) }\end{array}$} & \multicolumn{2}{|c|}{$\begin{array}{l}\text { Had received } \\
\text { transplant }\end{array}$} \\
\hline & $\begin{array}{l}\text { No }(\%) \\
\text { positive }\end{array}$ & $\begin{array}{c}\text { No } \\
\text { negative }\end{array}$ & & & Yes $(\%)$ & No \\
\hline Patients receiving dialysis $(n=146)$ & $34(23)+$ & 112 & $\begin{array}{l}46 \cdot 0 \\
48 \cdot 4\end{array}$ & $\begin{array}{l}46 \cdot 7(39 \cdot 9 \text { to } 63 \cdot 5) \\
34 \cdot 3(26 \cdot 1 \text { to } 42 \cdot 5)\end{array}$ & $\begin{array}{l}12(35) \\
32(29)\end{array}$ & $\begin{array}{l}22 \\
80\end{array}$ \\
\hline With chronic glomerulonephritis $(n=43)$ & $16(37) \ddagger$ & 27 & $\begin{array}{l}43 \cdot 7 \\
49 \cdot 0\end{array}$ & $\begin{array}{l}50 \cdot 7(30.9 \text { to } 70 \cdot 5) \\
53.6(24.8 \text { to } 82 \cdot 4)\end{array}$ & $\begin{array}{r}8(50) \\
15(56)\end{array}$ & $\begin{array}{r}8 \\
12\end{array}$ \\
\hline Without chronic glomerulonephritis $(n=103)$ & $18(17)$ & 85 & $\begin{array}{l}48 \cdot 4 \\
48 \cdot 5\end{array}$ & $\begin{array}{l}40 \cdot 5(21 \cdot 5 \text { to } 59 \cdot 5) \\
27 \cdot 9(19 \cdot 3 \text { to } 36 \cdot 5)\end{array}$ & $\begin{array}{r}4(22) \\
17(20)\end{array}$ & $\begin{array}{l}14 \\
68\end{array}$ \\
\hline $\begin{array}{l}\text { Normal controls }(n=53) \\
\text { Patients with systemic lupus erythematosus }(n=32)\end{array}$ & $\begin{array}{l}2(4) \\
6(19)^{\star}\end{array}$ & $\begin{array}{l}51 \\
26\end{array}$ & $\begin{array}{l}41 \cdot 3 \\
34 \cdot 2\end{array}$ & & & \\
\hline
\end{tabular}

$\mathrm{p}<0.05,+\mathrm{p}<0.005$ Compared with value in normal controls.
$\neq \mathrm{p}<0.025$ Compared with value in patients without chronic glomerulonephritis.

transplantation nor duration of dialysis, however, was associated with having a positive concentration. Only two of 16 patients with amyloidosis had positive concentrations.

Ten thrombotic events such as peripheral thrombosis, myocardial or cerebral infarction, or transient ischaemic attacks occurred after the antibody concentration was measured. Five patients had had positive and five negative concentrations. Thus having a positive antibody concentration predisposed to a thrombotic event significantly more commonly than did having a negative concentration $(p<0.05)$.

\section{Comment}

We have reported for the first time the prevalence of raised concentrations of antibodies to cardiolipin (over $10 \mathrm{U} / \mathrm{l}$ ) in patients receiving dialysis. Positive concentrations have previously been reported in patients with, for example, lupus erythematosus, rheumatoid arthritis, and Lyme disease ${ }^{1}$ but may also occur without an associated disease, in which case thrombotic symptoms are called the anticardiolipin syndrome. Antibodies may bind to the phosphodiester group of negatively charged phospholipids; reaction with such groups in platelets may change the function of these cells and predispose to thrombosis. ${ }^{4}$

Patients with uraemia have inhibited immune responses and are prone to severe infections. ${ }^{5}$ Previous episodes of infection in the patients in this study could not be completely mapped. Concentrations of antibody to cardiolipin were lower in the patients receiving dialysis than in those with systemic lupus erythematosus. Uraemic immune deficiency may, among other things, depress the production of antibodies. A high prevalence of positive concentrations of antibody to cardiolipin has been reported in rheumatoid arthritis, but in our study only two of 16 patients with amyloidosis had positive concentrations. In the patients with systemic lupus erythematosus positive concentrations were lower in those with uraemia than those without. These findings are compatible with depressed antibody production. On the other hand, concentrations of antibody to cardiolipin triggered by infections are generally lower than those in patients with lupus erythematosus or the primary cardiolipin syndrome. Patients with chronic glomerulonephritis had a predisposition to having antibodies to cardiolipin. This may be associated with an intrinsic immunological overreactivity in these patients.

Atherosclerosis is common in patients with chronic uraemia, over half of whom die of cardiac or vascular complications. These patients are often hypertensive and have various lipid abnormalities; uraemic toxins may damage the vascular wall. These factors contribute to the atherosclerotic process, complications of which may be enhanced by antibodies to cardiolipin. Longitudinal studies will tell whether this is so and whether therapeutic interventions are feasible.

This study was supported by a grant from the Liv och Hälsa Foundation and the Sigrid Jusélius Foundation.

1 Mackworth-Young CG, Loizou S, Walport MJ. Antiphospholipid antibodie and disease. $O \mathcal{F}$ Med 1989:72:767-77.

2 Brunner FP, Brynger H, Challah S, et al. EDTA Registry report. Renal replacement therapy in patients with diabetic nephropathy 1980-85. Nephrol Dial Transplant 1988;3:585-95.

3 Hughes GRV, Harris NN, Gharavi AE. The anticardiolipin syndrome. f Rheumatol 1986;13:486-9.

4 Hughes GRV. The Pross-White oration 1983. Connective tissue disease and the skin. Clin Exp Dermatol 1983;9:535-9.

5 Keane WF, Maddy MF. Host defences and infectious complications in maintenance haemodialysis patients. In: Maher JF, ed. Replacement of renal function by dialysis. Lancaster: Kluwer Academic, 1989:866-80.

(Accepted 17 April 1990)

\section{ONE HUNDRED YEARS AGO}

According to the reports which have appeared in the daily press, $\mathrm{Mr}$. Plowden, the magistrate sitting at the West London Police Court, recently gave expression to an opinion which it is to be feared a little more experience will lead him very seriously to regret. He appears to have found fault with a policeman for sending for the surgeon to see a prisoner who was "speechless drunk." The magistrate is reported to have expressed his opinion that it was not fair to the prisoner to send for a doctor without his consent, and then charge him the fee. He asked what was the good of sending for a doctor to see a drunken man? He declined to order the payment of the doctor's fee, and discharged the prisoner. In future, therefore, when the police find themselves in charge of a prisoner in a state of unconsciousness, they are to decide for themselves the strictly medical question as to the cause of this insensibility. It is not, of course, to be expected that a magistrate should recognise the nature of the circumstances which render a diagnosis in many of these cases exceedingly difficult, but it is certainly astonishing that any man occupying that position should be oblivious of the too numerous scandals which have occurred in times past. A few years ago the title "Drunk or Dying" was almost a standing heading in newspaper offices, so numerous were the cases in which unfortunate persons suddenly seized in the streets with apoplexy or some other serious disorder producing unconsciousness and stertorous breathing were consigned to a drunkard's cell for the night. The police are, no doubt, as a body intelligent and humane men, but if they are set tasks which they are quite incompetent to discharge, the inevitable consequence will be mistakes which will scandalise the public. The responsibility for these scandals will, to no small extent, rest upon the shoulders of magistrates who take upon themselves to express opinions at variance, not only with medical science, but with the hard facts of past experience. (British Medical fournal 1890;i:561) 